at the outset, such as sulphamezathine by mouth in doses of $\mathrm{I}$ to 2 grains per pound body weight per day in four-hourly doses. But if there is likely to be only a short delay in bacteriological diagnosis it may be better to wait for this and adjust the programme accordingly. If the very rare $B$. coli infection is found, i.e., a peritonitis or meningitis, streptomycin should be considered. The third step is the general treatment of the baby. Expert nursing is essential, and the prevention of superadded infection. The baby should be isolated and if the illness is at all severe then the expert services of a children's hospital or department should be sought. A watch must be kept on the state of hydration, especially if diarrhoea and vomiting complicate the picture, and steps taken, as by intravenous fluids, to remedy any serious de- hydration found. Similarly a watch must be kept on the haemoglobin level. Neonatal sepsis often leads to an increased haemolysis and in the presence of anaemia the baby has less chance of dealing with the infection. Iron may be given by mouth in the mild cases or a blood transfusion used if the haemoglobin drops below, say, 50 per cent. Haldane. Local treatment of abscesses and skin sepsis should follow accepted lines.

With this programme there is every prospect of success, save in the severer cases and in the smaller and possibly premature infants. Once recovery has been secured there should be no residual damage. Babies who are saved from death from neonatal sepsis have every prospect of growing up into normal and useful citizens.

\title{
THE ANAEMIAS OF INFANCY
}

\author{
By JaMes H. Hutchison, O.B.E., M.D., F.R.C.P., F.R.F.P.S.G. \\ Visiting Physician, Royal Hospital for Sick Children, Glasgow
}

Anaemia is one of the commonest causes of morbidity during the period of infancy. Baty (1947) analysed I,500 consecutive admissions to the Boston Floating Hospital ; 514 patients (34 per cent.) showed a definite anaemia, which in 92 per cent. was the result of infection, dietary deficiency, prematurity, or a combination of these factors. This analysis confirms the fact, already well-known to paediatricians, that the anaemias associated with iron deficiency are by. far the commonest of the blood diseases of infancy. Irondeficiency anaemia will, therefore, receive detailed consideration in this review. It is proposed also to discuss those anaemias of infancy in which recent advances have been made, leaving out of consideration anaemias rarely encountered in this country, e.g. Cooley's anaemia, sickle-cell anaemia, etc., and blood diseases in which anaemia is not the basic feature.

Any discussion on the subject of anaemia in infancy must be prefaced by some consideration of the normal range of values of the various blood components during this period. Failure to appreciate that these values differ from those accepted as physiological in later years has led frequently to errors in diagnosis.

\section{Haemoglobin Levels in the First Year of Life}

The extensive researches of Mackay (I93 I, r933(b)) produced the first authoritative and generally accepted British figures for the $\mathrm{Hb}$ content of the blood of infants during the first year of life (Fig. I). The estimations were made with a standardized Haldane haemoglobinometer in which 100 per cent. was assumed to be equivalent to $13.8 \mathrm{gm}$. of $\mathrm{Hb}$ per $100 \mathrm{cc}$. of blood. King and his co-workers (1947) by accepting iron determination as the most reliable method for estimating $\mathrm{Hb}$ have shown, however, that the modern B.S.I. Haldane-Gowers $\mathrm{Hb}$ Standard-British Standard I079 (1942)-is equivalent to $\mathrm{r}_{4} .8 \mathrm{gm}$. of $\mathrm{Hb}$, and not $13.8 \mathrm{gm}$. as previously assumed. It is, therefore, permissible to convert Mackay's (I933(b)) figures into terms of grammes of $\mathrm{Hb}$ per cent. on the assumption that a reading of roo per cent. on her haemoglobinometer was also equivalent to I4.8 gm. per cent.

It will be seen that the normal $\mathrm{Hb}$ level at birth is 143 per cent. (20.2 $\mathrm{gm}$. Hb per cent.). That this falls to 106 per cent. (15.7 gm.) in the first two weeks of life, and reaches 74 per cent. (II gm.) at three months. Thereafter it rises gradually to 
86 per cent. (12.7 gm.) at six months and remains at this level during the remainder of the first year of life. These figures given by Mackay as normal values were obtained as follows. The values during the first three months were averages from groups of breast. fed babies living in their own homes ; those for four months of age and upwards were based on $\mathrm{Hb}$ values obtained from infants receiving iron supplements, because it was assumed that these values would more truly represent the optimum than the lower values obtained at this age from 'healthy' babies not receiving additional iron. This assumption is justified by the finding that not only does iron raise the $\mathrm{Hb}$ level, it also diminishes the incidence of infection and increases the average gain in weight (Mackay, 1928).

It is opportune at this stage to discuss the physiological reasons for these fluctuations in $\mathrm{Hb}$ level during the first year. Zuelzer (1947) has pointed out that during foetal life oxygen tension in the blood is low and erythropoiesis is highly active, being found in other organs as well as the

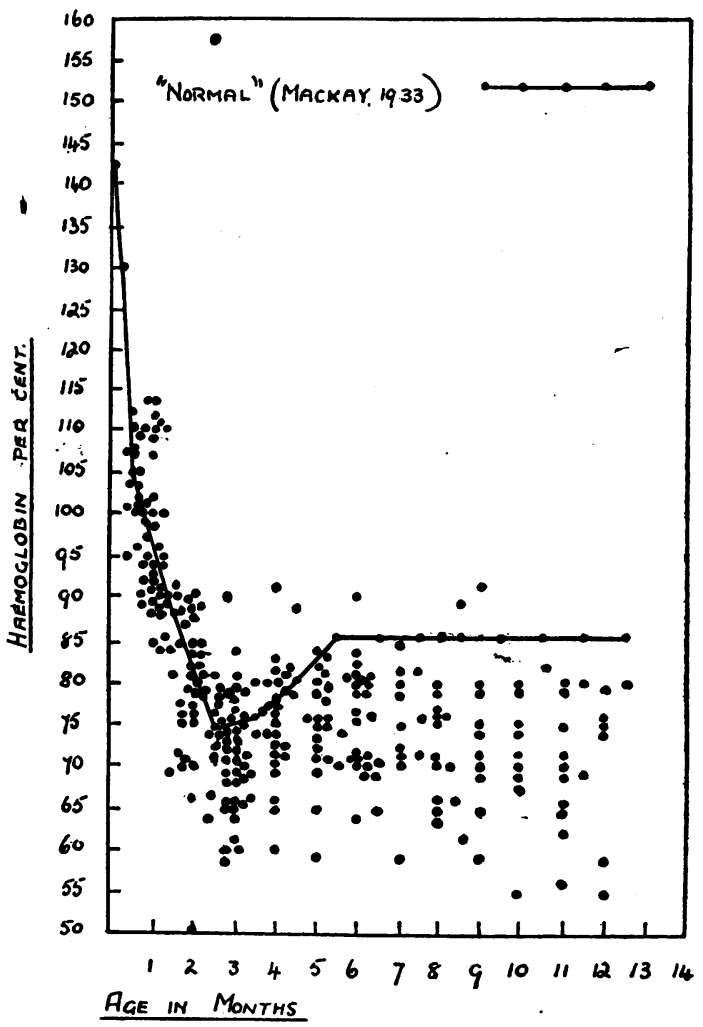

FiG. 1.-Haemoglobin percentage in 300 infants referred to age. bone marrow. The change at birth from placental to the more efficient pulmonary ventilation (by improving oxygenation) causes a quantitative reduction in erythroblastic regeneration, which is thereafter confined to the bone marrow. Furthermore, the first three months of life is a period of rapid growth with corresponding expansion of the blood volume and consequent dilution of the $\mathrm{Hb}$. Zuelzer (1947) considers that the combination of these two factors, decrease in the rate of erythropoiesis and increase in the blood volume probably plays the major part in producing the fall in $\mathrm{Hb}$ level during the period under consideration. The more pronounced $\mathrm{Hb}$ fall of prematurity (anaemia of prematurity) is due to an accentuation of these same factors, plus the fact that the hypothermia and inactivity of such infants suggest a low rate of oxygen consumption. Another factor which may play a part in causing the $\mathrm{Hb}$ level to fall after birth is haemolysis (Davidson, et al., '194I ; Fallon, I943 ; Lightwood, 1943). The evidence of such haemolysis, however, is not entirely satisfactory. Thus, Zuelzer (1947) states that there is increased haemolysis only during the first few days of life. Findlay (1946), however, found the most rapid fall in $\mathrm{Hb}$ and cell count during the second week, and later (Findlay, et al., 1947) he points out that the usual signs of increased haemolysis are absent; e.g. reticulocytosis, erythroblastaemia, etc. It should be stressed, however, that iron cannot prevent the fall in $\mathrm{Hb}$ level during the first three months (Mackay, I933(c)) nor can it prevent the ' anaemia of prematurity' at this period.

When the period of re-adjustment following the change from foetal to post-natal life has been completed the $\mathrm{Hb}$ level rises from I I $\mathrm{gm}$. at three months to $12.7 \mathrm{gm}$. at six months, to achieve which, iron is released from the liver (Gladstone, 1932). After six months iron requirements must be met from exogenous sources, failing which iron-deficiency anaemia makes its appearance.

\section{Red Cells in the First Year of Life}

The red cell count at birth averages $7,000,000$ per c.mm. (Whitby and Hynes, 1935). There is a steady decline to $5-5 \frac{1}{2}$ millions at the end of 1 2 days. A count of $4,000,000$ per c.mm. may be regarded as the lower limit of normal (Smith, 1947). At birth the peripheral blood may contain a few late normoblasts, Smith (1947) giving a figure of 3-10 per 100 white cells. Reticulocytes which may be 5-10 per cent. at birth (Whitby and Britton, 1946) reach the normal range of $0.5-1.5$ per cent. in a few days. Van Creveld (1932) records a mean corpuscular diameter of $8.4 \mathrm{I} \mu$ at birth, the adult figure being reached in a year to I8 months. 


\section{Nutritional Anaemia of Infancy}

The high incidence of iron-deficiency anaemia already mentioned has been amply confirmed in this country (Mackay, 1931 ; Fullerton, 1937; Colver, 1938 ; Hutchison, 1938(a)). Fig. I shows the findings in 300 infants examined in Glasgow by the author. From the fifth month onwards, values with few exceptions fall below normal.

\section{Aetiology}

Four factors may be operative. Maternal anaemia has been said to predispose the infant to anaemia during the first year of life (Strauss, I933; Mackay, I93I ; Parsons and Hawksley, 1933), although Fullerton (1937) from a convincing series of calculations concluded that the ironcontent of the newborn is independent of that of the mother. Deficient post-natal supply of iron in the form of unduly prolonged milk feeding is an important factor. Mackay (I93I), Hutchison (1938(a)) and others have shown that anaemia is frequent among both breast-fed and bottle-fed infants, more so the latter. Low birth rate is one of the major causes of anaemia during the first year, and prematures, twins, etc., are especially susceptible (Kunckel, 1915 ; Mackay, 193I ; Abt and Nagel, 1932 ; Magnusson, I935 ; Fullerton, 1937). The reason for this is that small babies grow more rapidly in relation to birth weight than larger infants, having at the same time a smaller blood volume and a smaller iron store in the liver The fourth and perhaps paramount factor is infection (Josephs, 1934 ; Fullerton, 1937 ; Diamond, 1945), which probably acts in several ways. It may interfere with ingestion or absorption of iron by producing anorexia, vomiting or diarrhoea. Recent work suggests also that in the presence of infection iron is diverted from the marrow and immobilized in the tissues (Cartwright, et al., 1946). This is true also of iron administered therapeutically. Anaemic infants are particularly susceptible to infection (Mackay, 1928) and a vicious circle is set up.

Iron-deficiency aniaemia is also common in coeliac disease due to a deficiency in absorption and this possibility should be kept in mind during later infancy (Neale, Smallwood and Shippam, I935; Hardwick, 1939).

\section{Clinical Picture}

The condition usually develops after the age of six months, earlier in prematures and twins. A severe case is illustrated by pallor, listlessness, splenomegaly and concomitant infection. The milder cases do not have a characteristic clinical picture and will only be spotted by blood examination which will show a microcytic hypochromic anaemia.

\section{Treatment}

(a) Preventive. This is best obtained by starting mixed feeding by five months with such foods as strained soup, sieved vegetables, eggyolk, fruit puree, cereals, etc. Mackay, et al. (1946) express the hope that the Ministry of Food may yet include in its provision of dried milks one fortified with iron. Such milks are commercially available, e.g. Hemolac (Cow and Gate) and Ferrolac (Glaxo). In the case of prematures the author has been in the habit of prescribing ferrous sulphate $\frac{1}{2}$ gr. thrice daily from the age of ten weeks.

(b) CURative. Large doses of inorganic iron, preferably in ferrous form, are effective. In animals copper is also essential in the treatment of anaemia (Waddell, Elvehjem, Steenbock and Hart, 1928). Josephs (1931), Lewis (1931) and Hutchison (1938(b)) advised the addition of copper to iron mixtures for use in human infants, although Mackay (1933(a)) regarded this as unnecessary. An effective prescription is :-

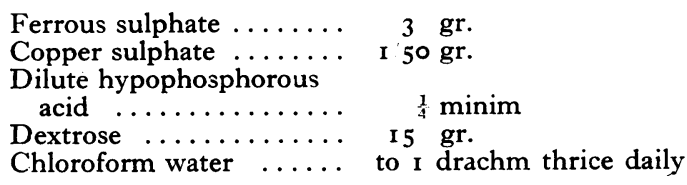

The dilute acid and dextrose prevent the oxidation of the ferrous iron into the poorly absorbed ferric salt (Mackay and Jacob, 1937). (Massive overdoses of inorganic iron have proved fatal to children (Forbes, 1947; Thomson, 1947) and parents should be warned accordingly.)

In the presence of infection iron is ineffective and resort must be had to blood transfusion.

\section{Megaloblastic Anaemias in Infancy}

It would seem probable in the light of recent work that megaloblastic anaemia in infancy is seen much more frequently than in the later stages of childhood. Davis (1944) succeeded in tracing reports of only 16 cases above the age of infancy and added three of his own; in none of these cases was a diagnosis of true Addisonian pernicious anaemia justified. Megaloblastic anaemia may also occur in coeliac disease and hepatic disorders but such is almost unknown during infancy. Zuelzer and Ogden (1946) have recently reported a series of 25 cases of megaloblastic anaemia in young infants, and they regard this syndrome to be ' of common occurrence in infancy.' In their cases the anaemia was severe, normochromic and usually macrocytic, and associated with leucopenia, neutropenia and thrombocytopenia. The liver was invariably increased in size ; the spleen was palpable in ten cases. The nutritional state was 
poor in over half the cases. In six there were signs of scurvy present. The bone marrow in every case was megaloblastic. Histamine-fast achlorhydria was found in eight of the nine cases tested. The anaemia responded satisfactorily to folic acid or liver extract. Since recovery was permanent without the need for maintenance therapy it is clear that these were not cases of Addisonian pernicious anaemia. Zuelzer and Ogden (1946) regard the principle aetiological factors to be infections and nutritional deficiencies, prolonged goat's milk feeding being especially liable to lead to temporary deficiency of the haemopoietic principle. Possible predisposing factors are age (infancy), race (white), prematurity and maternal anaemia causing a defective composition of breast milk. Siebenthal (1948) has recently described another two similar cases in infants who were permatently cured with folic acid.

The occurrence of true Addisonian anaemia in infancy has always been a matter for doubt. Peterson and Dunn (1946) report a probable case which : equired maintenance therapy.

\section{Treatment}

Megaloblastic anaemia can be expected to respond satisfactorily to treatment with liver extract or folic acid. In this connection, both Davis (1944) and Zuelzer and Ogden (1946) point out that a macrocytic anaemia may occur in the absence of megaloblastic erythropoiesis, e.g. in haemolytic states, etc., and such cases will not, of course, respond to treatment with liver extract or folic acid. In the megaloblastic anaemia of coeliac disease the blood response to treatment is often disappointing, although folic acid often produces great improvement in the child's well-being, weight gain and stool frequency although not affecting fat-absorption (Davidson, Girdwood and Innes, 1947).

\section{Anaemia of Scurvy}

Ascorbic acid deficiency depresses erythropoiesis (Israels, 1943). The anaemia is normocytic and normochromic, and is commonest between the age of nine months to one year. It responds to ascorbic acid 100-500 $\mathrm{mgm}$. daily, orally or intravenously.

\section{Congenital Haemolytic Disease of the Newborn (Erythroblastosis Foetalis)}

This is a familial disease in which the mother's blood contains agglutinins which destroy foetal or neonatal erythrocytes.

\section{Aetiology}

In I940, Landsteiner and Wiener observed that 85 per cent. of white peoples have an agglutinogen confined to the red cells which they called the
Rhesus factor because a similar factor is present in the blood of Rhesus monkeys (Landsteiner and Wiener, 194I). These people are referred to as Rhesus positive ( $\mathrm{Rh}+\mathrm{ve})$. The remaining $\mathrm{I}_{5}$ per cent. without agglutinogen are Rhesus negative $(\mathrm{Rh}-\mathrm{ve})$.

Mongolian peoples, South Sea Islanders and North American Indians are probably roo per cent. Rh + ve (Cappell, 1947).

$\mathrm{A} \mathrm{Rh}$ - ve person may produce an anti- $\mathrm{Rh}$ agglutinin if the $\mathrm{Rh}$ factor is introduced into his circulation-iso-immunization. This may occur in one of two ways :-

(I) The $\mathrm{Rh}$ - ve person may be immunized by receiving a transfusion of $\mathrm{Rh}+\mathrm{ve}$ blood or by an intramuscular injection of $\mathrm{Rh}+\mathrm{ve}$ blood (Diamond, . 1947).

(2) A Rh - ve female may be immunized by a $\mathrm{Rh}+\mathrm{ve}$ foetus if her husband is $\mathrm{Rh}+\mathrm{ve}$.

Thus if a $\mathrm{Rh}-$ ve female becomes pregnant with a $\mathrm{Rh}+$ ve foetus she may form anti-Rh agglutinins as the result of escape of $\mathrm{Rh}$ antigen from the foetus into her circulation. Late in pregnancy or during labour these anti-Rh agglutinins may enter the foetal circulation and destroy the erythrocytes. Levine (I94I), Levine, et al. (I94I), Race, et al. (1943), Mollison (1943) and others have shown that in the vast majority of cases of erythroblastosis there is, in fact, an $\mathrm{Rh}$ incompatibility between the mother ( $\mathrm{Rh}-\mathrm{ve})$ and foetus ( $\mathrm{Rh}$ + ve). The first baby is rarely affected unless previous iso-immunization has been produced in the mother by transfusion-hence the need for $\mathrm{Rh}$ typing of all females below child-bearing age before transfusion. When, however, sensitization does occur during a second or later pregnancy the outlook for future infants will depend on the husband's genotype. If he is homozygous $\mathrm{Rh}$ +ve, i.e. possessing two similar genes ( $R h(R h)$ every future baby will be affected with eryt iroblastosis. If he is heterozygous $R h+v e$, i.e. possessing two dissimilar genes ( $\mathrm{Rh} r \mathrm{rh}$ ) on a chromosome pair future babies will have a $50: 50$ chance of being unaffected, because the $\mathrm{Rh}$ - ve (rh rh) foetuses will be undamaged. Furthermore, a $\mathrm{Rh}$-ve woman is more likely to be sensitized if her husband is homozygous than if he is heterozygous.

However, there are other factors not yet understood which help to determine whether a $\mathrm{Rh}$ - ve woman will be sensitized by a $\mathrm{Rh}+$ ve foetus. In 13 per cent. of marriages the woman is $R h-v e$ and the man $\mathrm{Rh}+\mathrm{ve}$, and in ro per cent. of pregnancies a $\mathrm{Rh}$ - ve woman carries a $\mathrm{Rh}+\mathrm{ve}$ foetus, but the actual incidence of erythroblastosis is only somewhere in the region of 0.1 to 0.25 per cent. of all pregnancies. This discrepancy between actual incidence and possible incidence probably 
depends on such factors as ( 1 ) the prevalence of small families; (2) the efficiency of the placenta as a barrier to agglutinins ; (3) the varying antigenic potency of the $\mathrm{Rh}$ factor ; (4) the reaction of the mother in forming antibodies; (5) the varying response of the foetal tissues to $R h$ antibodies (Capon, 1947).

This simple differentiation of people into $\mathrm{Rh}+\mathrm{ve}(85$ per cent.) and $\mathrm{Rh}$ - ve (I 5 per cent.) was obtained by testing with one anti-Rh serum (Landsteiner and Wiener, 1940, 194I). This is the commonest serum and is referred to as 'standard' serum. Over 90 per cent. of cases of erythroblastosis can be explained on this basis. However, it has been demonstrated by British and American workers that the Rh factor is by no means a single entity. Unfortunately confusion and changes in nomenclature have made the essential facts difficult to understand. As Lancet (1948) points out 'Anybody wishing to follow developments in this field has had to master two languages - that of Wiener on the one hand and of Fisher and Race on the other.' It is not proposed in this predominantly clinical paper to enter fully into the complexities of the antigenic structure of the $\mathrm{Rh}$ factor: Readers are referred to the contributions of Wiener (I94I), Vogel, Rosenthal and Levine (1943), Mollison (1944), Taylor (1944), Race (1944), Coombs, Mourant and Race (I945 (a) and (b)), Mourant (1945), Cappell (1946), Whitby and Britton (1946), Gorer (1947).

In this country the Fisher-Race classification is preferred because it is simple and direct and gives an exact account of the antigens involved. The British workers deduced that six Rhesus antigens should exist, and that each of the two chromosomes concerned with the $\mathrm{Rh}$ factor carries three genes corresponding to three of the six antigens. The three mutually anti-thetical pairs of antigens were called C, D, E and c, d, e. The corresponding anti-sera are referred to as anti-C, or anti-c, etc. Thus eight possible antigen combinations can be inherited-CDe, cde, $\mathrm{cDE}$, cDe, cdE, $\mathrm{Cde}, \mathrm{CdE}$ and $\mathrm{CDE}$. Everybody inherits one of these combinations from each of his parents. Of the 36 possible genotypes the five commonest are :- $\mathrm{CDe} / \mathrm{cde}, \mathrm{CDe} / \mathrm{CDe}$, cde/cde, $\mathrm{CDe} / \mathrm{cDE}$ and $\mathrm{CDE} /$ cde. The original Rhesus factor is antigen $\mathrm{D}$. However, erythroblastosis may appear whenever a foetus contains an antigen or antigens not present in the mother. The existence of the rarer antigens explains most of the cases in which both mother and foetus appear to be $\mathrm{Rh}$ - ve or $\mathrm{Rh}+$ ve by testing with 'standard' serum.

A very few cases of erythroblastosis may b 2 due to heterospecific blood group pregnancy when the mother and foetus are of different Landsteiner (ABO) groups.
Clinical Picture

\section{Foetus AFFeCted}

(a) Stillbirth.

(b) Macerated foetus. with hepatic cirrhosis (Henderson, 1942).

(c) Hydrops foetalis. This is always fatal. The infant is born with dropsy and ascites. Spleen and liver are enlarged. Anaemia and erythroblastaemia are severe. Tissues and vernix are jaundiced. The placenta is large and pale. There may be hydramnios or maternal toxaemia. The antenatal radiograph may reveal a 'halo' of oedema surrounding the foetal skull. There may be a foetal systolic bruit.

\section{NeONATE AFFECTED}

(a) Icterus gravis neonatorum. The infant is born jaundiced or develops jaundice within a few hours, or rarely only after a few days. Liver and spleen are enlarged. Both bilirubin and excess urobilin are found in the urine. There may be spontaneous haemorrhage from skin or mucous membranes, etc. In severe cases the baby becomes feeble, drowsy, cold and dehydrated. Stools are normal in colour. The degree of anaemia is variable. Blood films show erythroblastaemia and reticulocytosis. Leucocytes are increased and some are immature forms. The Van den Bergh reaction is biphasic. Whitby and Britton (1946) and Sennott (1946) report finding erythrophagocytosis by monocytes in blood films.

\section{Sequelae}

A minority of surviving patients, about io per cent., show permanent effects.

(i) Kernicterus. May be suspected if the infant is very drowsy, shows head retraction or has convulsions. Infants so affected later exhibit permanent damage, e.g. mental deficiency, spastic diplegia, choreo-athetosis, etc.

(ii) Hepatic cirrhosis. It has even been suggested that Wilson's hepatolenticular cirrhosis may result from icterus gravis, but evidence that this is so is lacking.

(iii) Green discoloration of teeth (Ellis, 1938).

(iv) Polyostotic fibrous dysplasia. A curious bone condition associated with deformities and spontaneous fractures (Braid, I 939).

It should be stressed that no treatment at present available can prevent these sequelae.

(b) Congenital haemolytic anaemia. The infant becomes pale within a few hours, days or rarely weeks after birth. Icterus is slight or absent. Spleen and liver are enlarged. There is excess urobilinuria but no bilirubinuria. Anaemia with erythroblastaemia, reticulocytosis, and immature leucocytes is characteristic. The Van den 
Bergh reaction is indirect positive. This condition is much less severe and less common than icterus gravis.

\section{Pathology}

This has been fully described by Hawksley and Lightwood (r934), Parsons, Hawksley and Gittins (1933), Henderson (1942) and Gilmour (1944). The main features are widespread extramedullary erythropoiesis and deposition of haemosiderin. The liver in icterus gravis shows bile staining, necrosis or fibrosis, and bile thrombi in the canaliculi. In some 30 per cent. of cases coming to autopsy the basal ganglia and grey matter of the cord show symmetrical necrosis and bile staining -kernicterus (Zimmermann and Yannett, 1935).

\section{Diagnosis}

The diagnosis of: established erythroblastosis can usually be made on clinical and haematological grounds alone. However, it is possible by $\mathrm{Rh}$ typing with modern techniques to forecast that the unborn or newly born infant will develop signs of the disease. The practical importance of this is obvious.

Earlier work on $\mathrm{Rh}$ antibodies using 2 per cent. red cell suspensions in saline frequently failed to reveal maternal antibodies in known sensitized females. Wiener (1944) and Race (1944) showed that this was due to the presence in the maternal serum of another antibody distinct from agglutinin which had the effect of blocking the $R h$ receptors of the red cells and so rendering them incapable of being agglutinated by anti- $\mathrm{Rh}$ agglutinins. This type of antibody has been called 'incomplete' by Race, 'blocking' by Wiener, and ' hyper-immune' by Diamond. It tends to appear as sensitization increases with repeated pregnancies and a rising titre is associated with a more severe form of the disease in the foetus or neonate. Such a $\mathrm{Rh}+\mathrm{ve}$ child may appear $\mathrm{Rh}$ - ve because its $\mathrm{Rh}$ receptors have been blocked by this antibody in its serum.

Coombs, Mourant and Race (i945 (a) and (b)) have devised a test which will show conclusively that blocking antibody is present. It is based on the presumption that the sensitized cells of affected $R h+$ ve persons are coated with adsorbed blocking antibody which is so firmly united with the cells that it cannot be removed by washing in saline. Coomb's test is performed by treating the affected red cells with a powerful anti-humanglobulin rabbit serum when immediate agglutination takes place. Non-sensitized $\mathrm{Rh}+\mathrm{ve}$ cells are unaffected. The test may be carricd out in two ways :-

The direct test. By treating the washed red cells of the newborn child with anti-humanglobulin rabbit serum sensitization by $R h$ anti- bodies can be demonstrated within a few minutes. A positive Coomb's test indicates that the newborn in question will be affected by haemolytic disease.

The indirect test. This can be used to demonstrate the presence of blocking antibodies in the serum of a $\mathrm{Rh}$ - ve pregnant woman, indicating that the foetus or child will be affected by haemolytic disease. A saline suspension of appropriate genotype $\mathrm{Rh}+$ ve cells is treated with the maternal serum to be tested. . If blocking antibody is present agglutination will not take place, even in the presence of $\mathrm{Rh}$ agglutinins. If now the cells are washed in saline to remove any human serum and anti-human-globulin rabbit serum is then added immediate agglutination will take place. Routine ante-natal $\mathrm{Rh}$ testing may thus warn the clinician of impending trouble.

\section{Treatment}

Only icterus gravis and congenital haemolytic anaemia are susceptible to treatment and, in fact, mild cases recover spontaneously. Treatment consists in transfusion with $\mathrm{Rh}$ - ve blood of homologous ABO group or Group $O$. The mother's blood must, of course, not be used although her washed and packed $\mathrm{Rh}$-ve cells are satisfactory when $\mathrm{Rh}$ - ve donors are not available. Some paediatricians give rapeated small transfusions (no to $15 \mathrm{cc}$. per lb. of body weight), others give slow drip transfusions of larger amounts $(20$ to $25 \mathrm{cc}$. per lb. of body weight). Most workers advise transfusion only when the $\mathrm{Hb}$ falls to about i I.8 gm. per cent. (8o per cent. Haldane) on the grounds that the object of transfusion is to replace lost red cells with $\mathrm{Rh}$ - ve cells which will not be haemolyzed by $\mathrm{R} h$ agglutinins (Wiener and Sonn, I946 ; Parsons, 1947). Cappell (1946), however, advises transfusion as early as possible, even before signs of the disease develop on the doubtful grounds that this may lessen the risk of liver damage or kernicterus. American workers have recently advised the formidable procedure of exsanguination transfusion, and a variety of techniques have been described (Wiener and Wexler, 1946 ; Diamond, 1947; Wallerstein, 1947.; Arnold and Alford, 1948). The advantages of this procedure over the more straightforward transfusion have not yet been confirmed in this country.

There is no method at present of desensitizing the mother or of neutralizing her antibodies. The general consensus of opinion is against Caesarean section as soon as the foetus is viable, although induction of labour some time after the 36 th week is a rational procedure in the case of a woman with a climbing antibody titre during the latter half of pregnancy.

Affected infants should not be weaned, because although $\mathrm{Rh}$ antibodies are excreted in breast 
milk there is no evidence that they are absorbed (Cathie, 1947).

\section{Acholuric Jaundice}

Space does not permit of a detailed discussion of this well-known blood condition in which the outstanding features are haemolytic anaemia with splenomegaly, jaundice without bilirubin in the urine, spherocytosis, and increased fragility of the red cells to hypotonic saline. The congenital type which is transmitted through either sex as a Mendelian dominant characteristic may be recognized at birth or shortly afterwards. The existence of an acquired type has been doubted by Dawson (193I) and Vaughan (1936). However two papers from the workers in the South-West London Blood Supply Depot have proved the existence of the acquired type and added to our knowledge regarding the aetiology of the two types. Dacie and Mollison (1943) showed that normal erythrocytes transfused into five patients with congenital (familial) acholuric jaundice survived for a normal period of time, whereas in a control series of haemolytic anaemia of varied types cell destruction was rapid. On the other hand blood taken from a patient with familial acholuric jaundice, both before and after splenectomy, disappeared rapidly when transfused into a normal recipient. These observations favour the view that the basic abnormality in the congenital form of the disease is the formation of erythrocytes with an increased tendency to haemolysis. They would seem to contradict any theory which assigns a major role to abnormal destructive mechanisms.

Boorman, Dodd and Loutit (1946) performed Coombs' test (Coombs, et al., I945 (a) and (b)) on the washed red cells from 17 patients with congenital acholuric jaundice and five patients with acquired acholuric jaundice. In the first group the cells were not agglutinated by anti-human-serum rabbit serum, whereas the cells from all five patients of the second group were agglutinated by the reagent. There is, thus, a marked serological difference between the red cells in the congenital form of the disease and those in the acquired form, which suggests an aetiological difference also between the two conditions. The same workers also tested six cases of acquired haemolytic anaemia not conforming to the criteria of acholuric jaundice, i.e. the red cell fragility was within normal limits and they did not show spherocytosis. In all these six cases washed red cells were not agglutinated by anti-human-serum rabbit serum.

\section{Von Jaksch's Anaemia and Allied Disorders}

The picture implied by the term ' Von Jaksch's anaemia ' is a child between the ages of six months and three years with a severe hypochromic anaemia, splenomegaly and hepatomegaly, and in whom the peripheral blood shows erythroblastaemia and leucocytosis with immature cells present; the prognosis is relatively good. This syndrome, conforming to Von Jaksch's original meagre description, can be produced by blood diseases of varied types. Most cases fall into the group called 'chronic idiopathic haemolytic anaemia ' (Whitby and Britton, 1946), which is the commonest type of haemolytic anaemia met with in infancy after the neonatal period. Not all cases in this group conform to Von Jaksch's syndrome. In some cases the anaemia is normocytic or macrocytic with a high colour-index. Common to all cases, however, are the findings of reticulocytosis, positive indirect Van den Bergh reaction, excess urobilinuria, and a hyperplastic bone marrow. In cases with the Von Jaksch picture the prognosis seems to be better than in others where splenomegaly is less marked and in which the anaemia tends to drift into a hypoplastic phase. A more acute form of idiopathic haemolytic anaemia in which the onset is sudden with brisk fever, jaundice, and sometimes haemoglobinuria is the so-called Lederer's anaemia. Most but not all of these cases show a macrocytic anaemia with high colour index. In America there is a tendency to reserve the term Von Jaksch's anaemia for cases of Cooley's anaemia which, however, has additional characteristic features of its own and carries a grave prognosis. Furthermore, the signs described by Von Jaksch may also be produced by such varying states as iron deficiency in association with infection, congenital syphilis and leukaemia, and it seems doubtful whether the retention of the term 'Von Jaksch's anaemia ' serves a useful purpose. If the term is to be retained its use must not obscure the necessity for adequate investigation of every case by full blood and marrow studies, etc.

The acquired haemolytic anaemias form a most varied group of disorders about which Fisher (1947) aptly said ' The main features of the group are a confusing terminology, an unknown aetiology, an obscure prognosis, an unpredictable response to splenectomy, a liability to transient benefits and stormy reactions from blood transfusion, an absence of response to any other known haemopoietic aid, and a complete lack of satisfactory pathological basis.'

Recently at the International Conference of Physicians (1947), Van Creveld described a new type of haemolytic anaemia which he called 'splenic panhaematopenia,' and in which not only the erythrocytes but also leucocytes and sometimes platelets are lysed. It may be primary or 
secondary to such a condition as familial acholuric jaundice. A case with anaemia, leucopenia, and thrombocytopenia would usually be considered as an aplastic anaemia. In splenic panhaematopenia, however, there is a hyper-active bone marrow and splenic enlargement. Furthermore, splenectomy appears to offer a good chance of curing the condition. Van Creveld's cases are probably identical with the condition described by Wiseman and Doan (1942) as ' primary splenic neutropenia ' in which the clinical picture may be predominantly a severe neutropenia, or thrombocytopenic purpura, and in which a haemolytic anaemia is also present.

\section{Treatment}

The only two therapeutic measures likely to be of value are blood transfusion and splenectomy, and in any particular case it is impossible to predict the outcome. It is essential to maintain the patient with blood transfusions in the first instance. In some patients complete cure ensues, in others long remissions result, and in some, active haemolysis continues in spite of repeated transfusions. The best results are to be expected in cases of Lederer's anaemia and in the Von Jaksch syndrome. Splenectomy should be advised in cases with repeated remissions or when active haemolysis continues in spite of transfusion, although the results are not nearly so uniformly satisfactory as in congenital acholuric jaundice. Dameschek and Schwartz (1940) report that it may frequently be successful as a last resort in cases not responding to transfusion. It should not be delayed, however, until patients are moribund.

\section{BIBLIOGRAPHY}

AB'T, A. F., and NAGEL, B. R. (1932), F. Amer. Med. Ass., 98, 2270. ARNOLD, D. P., and ALFORD, K. M. (1948), ₹. Pediat., 32, I 13.

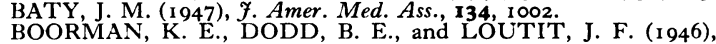
Lancet, 1, 812.

BRAID, F.'(1939), Arch. Dis. Childh., 14, 181.

CAPON, N. B. (I947), 'Diseases of Children,' edited by Paterson and Moncrieff, London, 4 th Ed.

CAPPELL, D. F. (1946), Brit. Med. F., 2, 601, 641

CARTWRIGHT; G. E., LAURITSEN, M. A., JONES, P. J. MERRILL, I. M., and WINTROBE, M. M. (I946), f. Clin. Invest., $25,65$.

CATHIE, I. A. B. (1947), Brit. Med. F., 2, 650 .

COLVER, T. (1938), Lancet, I, 245.

COOMBS, R. R. A., MOURANT, A. E., and RACE, R. R. (1945 (a)), Brit. F. Exper. Path., 26, 255 .

(1945 (b)), Lancet, 2,15 .
DACIE, J. V., and MOLLISON, P. L. (1943), Lancet, $1,550$.

DACIE, J. V., and MOLLISON, P. L. (1943), Lancet, 1 , 550.
DAMESHEK, W., and SCHWARTZ, S. O. (1940), Medicine, 19,

DAVIDSON, L. S. P., GIRDWOOD, R. H., and INNES, E. M. (1947), Lancet, I, $5 \mathrm{I}$ I.

DAVIDSON, L. T., MERRITT, K. K., and WEECH, A. A. (1941), Amer. F. Dis. Child., 61, 958.

DAVIS, L. J. (1944), Arch. Dis. Childh., 19, 147.

DAWSON OF PENN (1931), Brit. Med. F., r, 921 .

DIAMOND, L. K. (1945), ' Textbook of Pediatrics,' edited by Mitchell and Nelson, Philadelphia.

DIAMOND, L. K. (1947), Proc. Roy. Soc. Med., 40, 546.

ELLIS, R. W. B. (1938), Proc. Roy. Soc. Med., 31, 767.
ELVEHJEM, C. A., DUCKLES., D., and MENDENHALL, D. R. (1937), Amer. F. Dis. Child., 53, 785 .

FALLON, M. (1943), F. Pediat., 23, 721 .

FINDLAY, L. (1946), Arch. Dis. Childh., 21, 195.

FINDLAY, L., HIGGINS, G., and STANIER, M. W. (1947), Arch. Dis. Childh., 22, 65.

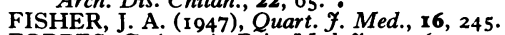

FORBES, G. (1947), Brit. Med. ₹., 1, 367.

FULLERTON, H. W. (1937), Arch. Dis. Childh., 12, 91.

GILMOUR, J. R. (1944), Arch. Dis. Childh., 19, 1, 12, 21.

GLADSTONE, S. A. (1932), Amer. F. Dis. Child., 44, 81.

GORER, P. A. (I947), 'Child Health and Development,' edited by Ellis, London.

HARDWICK, C. (1939), Arch. Dis. Childh., 14, 279.

HAWKSLEY, J. C., and LIGHTWOOD, R. (1934), Quart. f. Med., 3, 155 .

HENDERSON, J. L. (1942), Arch. Dis. Childh., 17, 49.

HUTCHISON, J. H. (1938 (a)), Arch. Dis. Childh., 13, 355.

HUTCHISON, J. H. (1938 (b)), Quart. F. Med., 7, 397.

ISRAELS; M. C. G. (1943), Lancet, 1 , 170.

JOSEPHS, H. W. (1931), Bull. Fohns Hopk. Hosp., 49, 246.

JOSEPHS, H. W. (1934), Bull. Johns Hopk. Hosp., 55, 259.

KING, E. J., GILCHRIST, M., WOOTON, I. D. P., DONALDSON, R., SISSON, R. B., MACFARLANE, R. G., JOPE, H. M., O'BRIEN, J. R. P., PETERSON, J. M., and STRANGEWAYS, D. H. (1947), Lancet, 2, 789.

KUNCKEL, D. (1915), Ztschr. f. Kinderheilk., 13, 1ог.

Lancet (1948), Annotation, $1,329$.
LANDSTEINER, K., and WIENER, A. S. (1940), Proc. Soc. Exp.

Biol. Med., 43, 223.
LANDSTEINER, K., and WIENER, A. S. (194I), F. Exper. Med.,

74, 309. (1941), Amer. F. Clin. Path., 11, 898.

LEVINE, P., BURNHAM, L., KATZIN, E. M., and VOGEL, P. (194I). Amer. F. Obst. Gynaec., 42, 925.

LEWIS, M. S. (1931), f. Amer. Med. Ass., 96, 1135.

LIGHTWOOD, R. (1943), Practitioner, 150, 286.

MACKAY, H. M. M. (1928), Arch. Dis. Childh., 3, I 17.

MACKAY, H. M. M. (1931), Med. Res. Council Spec. Rep. Ser., Lond., No. 157 .

MACKAY,, H. M. M. (1933 (a)), Arch. Dis. Childh., 8, 145.

MACKAY, H. M. M. (1933(b)), Ibid., $22 \mathrm{I}$.

MACKAY, H. M. M. (1933(c)), Ibid., 251.

MACKAY, H. M. M., and JACOB, L. E. (1937), Lancet, 2, 570.

MACKAY, H. M. M., DOBBS, R. H. BINGHAM, K., and

MARTIN, W. J. (1946), Arch. Dis. Childh., $21,145$. MOLLIISON, P. L. (1943), Arch. Dis. Childh., 18, 161.

MOLLISON, P: L. (1944), Post Grad. Med. F., 20, 17.

MOURANT, A. E. (1945), Nature, 155, 542 .

NEALE, A. V., SMALLWOOD, W. C., and SHIPPAM, F. (1935), Amer. F. Dis. Child., 50, 1502.

PARSONS, L. G. (1947), Lancet, I, 815.

PARSONS, L. G., and HAWKSLEY, J. C. (1933), Arch. Dis. Childh., 8, 117.

PARSONS, L. G., HAWKSLEY, J. C., and GITTINS, R. (1933), Arch. Dis. Childh., 8, 159.

PETERSON, J. C., and DUNN, S. C. (1946), Amer. F. Dis. Child. $71,252$.

RACE, R. R. (1944), Nature, 153, 771. McFARLÁNE, M. N. (1943), Brit. Med. F., 2, 289, 690 .

SENNOTT, J. S. (1946), Amer. F. Dis. Child., 71, 269.

SIEBENTHAL, B. J. (1948), Ұ. Pediat., 32, I88.

SMI'TH, C. H. (1947), Ұ. Amer. Med. Ass., 134, 992.

STRAUSS, M. B. (1933), Ұ. Clin. Invest., 12, 345 .

TAYLOR, G: L. (1944), Brit. Med. Bull., 2, 160.

THOMSON, J. (1947), Brit. Med. $\mathcal{F}_{\text {., }}$ 1, 640.

VAN CREVELD, S. (1932), Amer. $\ddot{\mathcal{F}}$. Dis. Child., 44, 701.

VAUGHAN, J. M. (1936), 'The Anaemias,' London.

VOGEL, P., ROSENTHAL, N., and LEVINE, P. (1943), Amer.

F. Clin., Path., r3, I.
WADDELL, J., ELVEHEM, C. A., STEENBOCK, H., and HART, E. B. (1928), $\mathcal{Y}$. Biol. Chem., 77, 777.

WALLERSTEIN, H. (1947), Amer. 尹. Dis. Child., 73, '9. of the Blood,' London, 5 th Ed.

WHITBY, L. E. H., and HYNES, M. (1935), f. Path. Bact., 40, 219.

WIENER, A. S. (194I), Arch. Path., 32, 227.

WIENER, A. S. (1944), Proc. Soc. Exp. Biol., 56, 173

WIENER, A. S., and SONN, E. B. (1946), Amer. F. Dis. Child., WIENER, A. S., and WEXLER, I. B. (1946), f. Lab. Clin. Med.,

WISEMAN, B. K., and DOAN, C. A. (1942), Ann. Intern. Med.,

I6, I097. Dis. Child., 49, 418.

ZUELZER, W. W. (1947), f. Amer. Med. Ass., 134, 998.

ZUELZER, W. W., and OGDEN, F. N. (1946), Amer. F. Dis. Child., 71, 221. 